\title{
The Cedar Project: mortality among young Indigenous people who use drugs in British Columbia
}

\author{
Kate Jongbloed MSc, Margo E. Pearce PhD, Sherri Pooyak MSW, David Zamar MEng, Vicky Thomas, Lou Demerais, \\ Wayne M. Christian, Earl Henderson MA, Richa Sharma MA, Alden H. Blair MSc, Eric M. Yoshida MD MHSc, \\ Martin T. Schechter MD PhD, Patricia M. Spittal PhD; for the Cedar Project Partnership
}

Cite as: CMAJ 2017 November 6;189:E1352-9. doi: 10.1503/cmaj.160778

See related article at www.cmaj.ca/lookup/doi/10.1503/cmaj.171002

Visual abstract available at www.cmaj.ca/lookup/suppl/doi:10.1503/cmaj.160778/-/DC1

\begin{abstract}
BACKGROUND: Young Indigenous people, particularly those involved in the child welfare system, those entrenched in substance use and those living with HIV or hepatitis $\mathrm{C}$, are dying prematurely. We report mortality rates among young Indigenous people who use drugs in British Columbia and explore predictors of mortality over time.
\end{abstract}

METHODS: We analyzed data collected every 6 months between 2003 and 2014 by the Cedar Project, a prospective cohort study involving young Indigenous people who use illicit drugs in Vancouver and Prince George, BC. We calculated age-standardized mortality ratios using
Indigenous and Canadian reference populations. We identified predictors of mortality using time-dependent Cox proportional hazard regression.

RESULTS: Among 610 participants, 40 died between 2003 and 2014, yielding a mortality rate of 670 per 100000 person-years. Young Indigenous people who used drugs were 12.9 (95\% confidence interval $[\mathrm{Cl}]$ 9.2-17.5) times more likely to die than all Canadians the same age and were $7.8(95 \% \mathrm{Cl} 5.6-$ 10.6) times more likely to die than Indigenous people with Status in BC. Young women and those using drugs by injection were most affected. The lead- ing causes of death were overdose ( $n=$ $15[38 \%])$, illness ( $n=11[28 \%])$ and suicide $(n=5[12 \%])$. Predictors of mortality included having hepatitis $\mathrm{C}$ at baseline (adjusted hazard ratio [HR] 2.76, $95 \% \mathrm{Cl} 1.47-5.16)$, previous attempted suicide (adjusted HR 1.88, 95\% Cl 1.013.50) and recent overdose (adjusted HR 2.85, 95\% Cl 1.00-8.09).

INTERPRETATION: Young Indigenous people using drugs in $\mathrm{BC}$ are dying at an alarming rate, particularly young women and those using injection drugs. These deaths likely reflect complex intersections of historical and present-day injustices, substance use and barriers to care. ndigenous leaders in Canada are concerned that their young people are dying prematurely, particularly those involved in the child welfare system, those entrenched in substance use and those living with HIV or hepatitis C virus (HCV). ${ }^{1-3}$ The young Indigenous population is growing rapidly, and these lives must be fostered and realized, rather than ended prematurely. ${ }^{4}$ In British Columbia, the 2010 age-standardized mortality rate for Indigenous people with Status was 76.3 per 10000 , compared with 45.5 per 10000 for other residents. ${ }^{5}$ Elevated mortality among urban Indigenous people has been observed for alcohol-related deaths, vehicle crashes and infectious diseases, with disparities especially pronounced among young people aged 25-34 years. ${ }^{6}$ The deaths and disappearances of more than 1000 Indigenous women are the subject of a national inquiry. ${ }^{7,8}$

Elevated mortality among Indigenous people in Canada has historical roots in colonial policy. ${ }^{9,10}$ Colonization has involved forced displacement from traditional territories, epidemics, systemic violence and death. ${ }^{9,11}$ Between 1874 and 1996, more than 150000 Indigenous children were removed from their families and placed in residential schools. ${ }^{10,11}$ The system has been described as "cultural genocide," involving physical, sexual and emotional abuse, as well as institutionalized neglect, medical experimentation and devaluation of cultural identity. ${ }^{10,12,13}$ The Truth and Reconciliation Commission of Canada estimated that residential school students were 4 to 8 times more likely to die than Canadian school-aged children in the general population, ${ }^{10}$ but also suggested that this was a substantial underestimate, given mass destruction of documents. ${ }^{10}$ Reports by the families of children who went missing highlight the degree of underestimation. ${ }^{14}$ 
As the residential school era came to a close, apprehension into the child welfare system escalated. ${ }^{10,15}$ Today, nearly $4 \%$ of Indigenous children in Canada are in care, compared with $0.3 \%$ of non-Indigenous children. ${ }^{16}$ Although less than $10 \%$ of children in $\mathrm{BC}$ are Indigenous, they account for $60 \%$ of those in care. ${ }^{1}$ Children in care in that province are 3.7 times more likely to die than other residents the same age, with suicide, homicide and infectious disease among the leading causes of death. ${ }^{17}$ It has been suggested that the cumulative impact of the historical injustices outlined above has been elevated rates of substance use and addictions among young Indigenous people. ${ }^{10,18}$ However, there is a paucity of research addressing the risk factors associated with premature death, including overdose and suicide. In this study, we report mortality rates among young Indigenous people who use drugs in $\mathrm{BC}$ and explore predictors of mortality over time.

\section{Methods}

\section{Study design}

The Cedar Project is a cohort study involving 610 young Indigenous people who use injection and non-injection drugs in Vancouver and Prince George, BC, on Coast Salish and Lheidli T'enneh territories, respectively. ${ }^{19}$ Participants were recruited through referral by health care providers, community outreach or word of mouth, and were eligible if they self-identified as Indigenous, were 14-30 years old, had smoked or injected drugs in the 30 days before enrolment (with confirmation by saliva screening) and provided informed consent. We defined "Indigenous" as referring to people who are descendants of the First Peoples of North America, including Métis, Aboriginal, First Nations, Inuit, and Status and non-Status Indians.

At enrolment, participants completed an interviewer-administered questionnaire on sociodemographic characteristics, trauma, drug use and sexual vulnerability. Venous blood samples were tested for HIV and HCV. Trained nurses provided pre- and post-test counselling. Participants were invited to return for test results and referrals to care. Staff worked to secure physical and emotional support, including traditional healing and drug treatment. Participants returned every 6 months for follow-up. Honoraria were provided for participation.

\section{Outcome measures}

For deaths in the Cedar Project cohort between 2003 and 2014, we sought confirmation through the Coroners Service of British Columbia, BC's Vital Statistics Agency, news reports and obituaries.

Additional variables included age (years), sex (male/female), city (Prince George/Vancouver) and parental residential school attendance (yes/unsure/no). At baseline, participants were asked if they had ever (yes/no) been taken into foster care, been forced to have sex or been molested, been paid for sex, injected drugs, been incarcerated, received methadone, attempted suicide, overdosed or received a mental health diagnosis. Additional baseline questions included age at initiation of drug use other than marijuana (years) and age at first injection (years). At each visit, participants were asked about the following experiences in the prior 6 months (yes/no): sex work, sexual assault, injection drug use, incarceration, suicide ideation, sleeping on the street and overdose.

\section{Statistical analysis}

We calculated crude mortality rates overall and by subgroups using person-time methods, and we calculated $95 \%$ confidence intervals (Cls) using the Poisson distribution. We calculated indirect standardized mortality ratios using Indigenous and Canadian reference populations. We ascertained age-specific mortality rates of Canadians, including Indigenous people, for 2008 (the midpoint of the study period) using Statistics Canada data compiled from comprehensive population-level provincial and territorial vital statistics registries. ${ }^{20}$ We ascertained mortality rates for all Indigenous people with Status in BC from the report entitled First Nations Health and Well-Being: Interim Update, based on data from the BC Vital Statistics Agency and published by the Office of the Provincial Health Officer of $\mathrm{BC}$ and the First Nations Health Authority. ${ }^{21}$ We censored the analyses on Aug. 31, 2014. We used time-dependent Cox proportional hazard regression to identify predictors of mortality.

Although the amount of missing information was small (6\%), retaining only participants with complete observations resulted in a substantial reduction of the sample size (list-wise deletion of $87 \%$ of observations). For multiple imputation, we used random $k$ nearestneighbour imputation with R package VIM. A total of 100 unique data sets were produced. ${ }^{22}$ We pooled parameter estimates for all imputed data sets for more accurate estimates than those with only one imputation. ${ }^{23}$ To avoid overfitting, we used purposeful selection to identify a subset of covariables to be included in the final model. ${ }^{24}$ At the model-selection stage, we entered only those variables that were significant at a $p$ value cut-off of 0.25 in the bivariable analysis. We performed forward and backward stepwise model selection using the Akaike information criterion, which does not depend on the use of $p$ values, on each imputed data set. We included in the final model only those covariables appearing in at least half of the models from the imputed data sets. ${ }^{25,26}$

We observed elevated mortality among women, and therefore conducted a sensitivity analysis to assess changes in the final model with the forced inclusion of sex.

\section{Ethics approval}

This study followed the Tri-Council Policy Statement: Ethical Conduct for Research Involving Humans, with attention to chapter 9, which pertains to research involving Indigenous peoples. Indigenous collaborators and investigators, collectively known as the Cedar Project Partnership, governed the entire research process and approved this manuscript. The UBC Providence Health Care Research Ethics Board approved the study. Honouring participants who have passed away, through annual memorials with traditional foods and ceremony, remains a critical part of our culturally safe approach.

\section{Results}

Among the 610 participants, 293 (48.0\%) were young women, and $304(49.8 \%)$ lived in Vancouver (Table 1). Substantial proportions of participants experienced being taken into care, childhood sexual abuse, incarceration, suicidal ideation, binge drug use and sex work. In total, 511 (83.8\%) completed at least one follow-up, and we accumulated data for a total of 5967 person-years. 
Table 1 (part 1 of 2): Baseline characteristics of young Indigenous people who used illicit drugs

Sex; no. (\%) of participants*

\begin{tabular}{|c|c|c|c|}
\hline Characteristic & $\begin{array}{c}\text { Men } \\
n=317\end{array}$ & $\begin{array}{l}\text { Women } \\
n=293\end{array}$ & $\begin{array}{c}\text { All } \\
n=610\end{array}$ \\
\hline \multicolumn{4}{|l|}{ Demographic } \\
\hline \multicolumn{4}{|l|}{ City } \\
\hline Vancouver & $152(47.9)$ & $152(51.9)$ & $304(49.8)$ \\
\hline Prince George & $165(52.1)$ & $141(48.1)$ & $306(50.2)$ \\
\hline Age, yr, median (IQR) & $23.8(20.8-27.4)$ & $23(20.1-25.9)$ & $23.5(20.5-26.9)$ \\
\hline \multicolumn{4}{|l|}{ Trauma } \\
\hline Either parent attended residential school & $n=313$ & $n=290$ & $n=603$ \\
\hline Yes & $146(46.6)$ & $133(45.9)$ & $279(46.3)$ \\
\hline No & $67(21.4)$ & $66(22.8)$ & $133(22.0)$ \\
\hline Unsure & $100(31.9)$ & $91(31.4)$ & $191(31.7)$ \\
\hline Ever removed from biological parents & $n=316$ & $n=293$ & $n=609$ \\
\hline Yes & $193(61.1)$ & $201(68.6)$ & $394(64.7)$ \\
\hline No & $123(38.9)$ & $92(31.4)$ & $215(35.3)$ \\
\hline Childhood sexual abuse ( $\leq 15 \mathrm{yr}$ ) & $n=311$ & $n=288$ & $n=599$ \\
\hline Yes & $83(26.7)$ & $182(63.2)$ & $265(44.2)$ \\
\hline No & $228(73.3)$ & $106(36.8)$ & $334(55.8)$ \\
\hline $\begin{array}{l}\text { Age at first sexual abuse, } \dagger \text { yr, } \\
\text { median (IQR) }\end{array}$ & $6(4.0-8.0)$ & $6(4.0-9.0)$ & $6(4.0-9.0)$ \\
\hline Ever incarcerated & $n=315$ & $n=293$ & $n=608$ \\
\hline Yes & $238(75.6)$ & $161(54.9)$ & $399(65.6)$ \\
\hline No & $77(24.4)$ & $132(45.1)$ & $209(34.4)$ \\
\hline Ever admitted to hospital for mental illness & $n=311$ & $n=288$ & $n=599$ \\
\hline Yes & $50(16.1)$ & $60(20.8)$ & $110(18.4)$ \\
\hline No & $261(83.9)$ & $228(79.2)$ & $489(81.6)$ \\
\hline Ever diagnosed with mental illness & $n=314$ & $n=293$ & $n=607$ \\
\hline Yes & $104(33.1)$ & $77(26.3)$ & $181(29.8)$ \\
\hline No & $210(66.9)$ & $216(73.7)$ & $426(70.2)$ \\
\hline Ever thought about suicide & $n=316$ & $n=293$ & $n=609$ \\
\hline Yes & $167(52.8)$ & $155(52.9)$ & $322(52.9)$ \\
\hline No & $149(47.2)$ & $138(47.1)$ & $287(47.1)$ \\
\hline Ever attempted suicide & $n=316$ & $n=293$ & $n=609$ \\
\hline Yes & $100(31.6)$ & $124(42.3)$ & $224(36.8)$ \\
\hline No & $216(68.4)$ & $169(57.7)$ & $385(63.2)$ \\
\hline \multicolumn{4}{|l|}{ Substance use } \\
\hline $\begin{array}{l}\text { Age at initiation of non-injection drug use, yr, } \\
\text { median (IQR) }\end{array}$ & $16(14.0-19.0)$ & $16.2(14.0-18.0)$ & $16(14.0-18.0)$ \\
\hline Ever injected & $n=317$ & $n=293$ & $n=610$ \\
\hline Yes & $148(46.7)$ & $190(64.8)$ & $338(55.4)$ \\
\hline No & $169(53.3)$ & $103(35.2)$ & $272(44.6)$ \\
\hline Age at first injection, $\ddagger$ yr, median (IQR) & $18(16.0-22.0)$ & $17(15.0-20.0)$ & $18(15.0-21.0)$ \\
\hline Ever overdosed & $n=315$ & $n=290$ & $n=605$ \\
\hline Yes & $79(25.1)$ & $101(34.8)$ & $180(29.8)$ \\
\hline No & $236(74.9)$ & $189(65.2)$ & $425(70.2)$ \\
\hline
\end{tabular}


Table 1 (part 2 of 2): Baseline characteristics of young Indigenous people who used illicit drugs

\begin{tabular}{|c|c|c|c|}
\hline \multirow[b]{2}{*}{ Characteristic } & \multicolumn{3}{|c|}{ Sex; no. (\%) of participants* } \\
\hline & $\begin{array}{c}\text { Men } \\
n=317\end{array}$ & $\begin{array}{l}\text { Women } \\
n=293\end{array}$ & $\begin{array}{c}\text { All } \\
n=610\end{array}$ \\
\hline Binge injection drug use & $n=286$ & $n=265$ & $n=551$ \\
\hline Yes & $25(8.7)$ & $33(12.5)$ & $58(10.5)$ \\
\hline No & $261(91.3)$ & $232(87.5)$ & $493(89.5)$ \\
\hline Binge non-injection drug use & $n=312$ & $n=290$ & $n=602$ \\
\hline Yes & $166(53.2)$ & $144(49.7)$ & $310(51.5)$ \\
\hline No & $146(46.8)$ & $146(50.3)$ & $292(48.5)$ \\
\hline Daily or more injection of cocaine & $n=317$ & $n=293$ & $n=610$ \\
\hline Yes & $32(10.1)$ & $55(18.8)$ & $87(14.3)$ \\
\hline No & $285(89.9)$ & $238(81.2)$ & $523(85.7)$ \\
\hline $\begin{array}{l}\text { Daily or more injection of crystal } \\
\text { methamphetamine }\end{array}$ & $n=317$ & $n=292$ & $n=609$ \\
\hline Yes & $14(4.4)$ & $6(2.1)$ & $20(3.3)$ \\
\hline No & $303(95.6)$ & $286(97.9)$ & $589(96.7)$ \\
\hline Daily or more injection of opiates & $n=317$ & $n=293$ & $n=610$ \\
\hline Yes & $26(8.2)$ & $84(28.7)$ & $110(18.0)$ \\
\hline No & $291(91.8)$ & $209(71.3)$ & $500(82.0)$ \\
\hline Ever received methadone treatment & $n=317$ & $n=290$ & $n=607$ \\
\hline Yes & $20(6.3)$ & $75(25.9)$ & $95(15.7)$ \\
\hline No & $297(93.7)$ & $215(74.1)$ & $512(84.3)$ \\
\hline \multicolumn{4}{|l|}{ Sexual vulnerability } \\
\hline Ever been paid for sex & $n=242$ & $n=293$ & $n=535$ \\
\hline Yes & $54(22.3)$ & $206(70.3)$ & $260(48.6)$ \\
\hline No & $188(77.7)$ & $87(29.7)$ & $275(51.4)$ \\
\hline \multicolumn{4}{|l|}{ HIV or HCV infection } \\
\hline HIV infection & $n=314$ & $n=293$ & $n=607$ \\
\hline Yes & $14(4.5)$ & $34(11.6)$ & $48(7.9)$ \\
\hline No & $300(95.5)$ & $259(88.4)$ & $559(92.1)$ \\
\hline HCV infection & $n=308$ & $n=283$ & $n=591$ \\
\hline Yes & $74(24.0)$ & $120(42.4)$ & $194(32.8)$ \\
\hline No & $234(76.0)$ & $163(57.6)$ & $397(67.2)$ \\
\hline $\begin{array}{l}\text { Note: } \mathrm{HCV}=\text { hepatitis C virus, IQR = interqu } \\
{ }^{*} \text { Except where indicated otherwise. } \\
\text { †Among the subset of people who reportec } \\
\text { †Among the subset of people who reportec }\end{array}$ & & & \\
\hline
\end{tabular}

Between 2003 and 2014, our team identified 45 deaths. Of these, 43 were confirmed by the following means: reports from the BC Coroner's Service (28 completed, 1 under investigation), death registrations from BC's Vital Statistics Agency $(n=9)$, news reports $(n=3)$ and obituaries $(n=2)$. Two deaths remained unconfirmed and were right-censored. Three of the confirmed deaths were censored because they occurred among recently recruited participants lacking longitudinal data. Therefore, 40 deaths were included in the analysis.

Among the 40 participants who died, 26 (65\%) were women (Table 2). The leading cause of death was overdose $(n=15)$, followed by illness $(n=11)$ and suicide $(n=5)$. Six participants
(3 men, 3 women) died from HIV, HCV or HIV/HCV co-infection.

The overall mortality rate was $670(95 \% \mathrm{Cl} 479-913)$ per 100000 person-years (Table 3). Among young women, the rate was 916 per 100000 person-years and among young men, 447 per 100000 person-years. Among participants who used injection drugs, the rate was 986 per 100000 person-years.

Compared with all Canadians the same age, young Indigenous people who used drugs were $12.9(95 \% \mathrm{Cl}$ 9.2-17.5) times more likely to die. Young Indigenous women were $15.8(95 \% \mathrm{Cl} 10.3-$ 23.2) times and young Indigenous men were $8.5(95 \% \mathrm{Cl} 4.7-14.3)$ times more likely to die. Mortality among participants who used injection drugs was $18.4(95 \% \mathrm{Cl} 12.6-25.9)$ times higher. 
Compared with all Indigenous people with Status in BC, participants were $7.8(95 \% \mathrm{Cl} 5.6-10.6)$ times more likely to die. Young women were $9.6(95 \% \mathrm{Cl} 6.3-14.1)$ times and young men were $5.2(95 \% \mathrm{Cl} 2.8-8.7)$ times more likely to die. Participants who used injection drugs were 11.1 (95\% Cl 7.6-15.7) times more likely to die.

In bivariable Cox regression analyses (Table 4), the factors associated with mortality were female sex, ever attempting suicide, ever having injected drugs, recent injection drug use, recent daily cocaine injection, recent daily opiate injection, recent overdose and HCV infection. In the multivariable analysis (Table 5), factors that remained significantly associated with mortality were HCV infection at baseline, ever attempting suicide and recent overdose.

Table 2: Causes of death among young Indigenous people who use drugs in British Columbia, Canada (2003-2014)

\begin{tabular}{|c|c|c|c|}
\hline \multirow[b]{2}{*}{ Cause of death } & \multicolumn{3}{|c|}{ Group; no. (\%) } \\
\hline & $\begin{array}{c}\text { All } \\
n=40\end{array}$ & $\begin{array}{c}\text { Women } \\
n=26\end{array}$ & $\begin{array}{c}\text { Men } \\
n=14\end{array}$ \\
\hline Overdose & $15(38)$ & $11(42)$ & $4(29)$ \\
\hline $\begin{array}{l}\text { Substance use } \\
\text { (not overdose) }\end{array}$ & $3(8)$ & $1(4)$ & $2(14)$ \\
\hline Suicide & $5(12)$ & $4(15)$ & $1(7)$ \\
\hline Homicide & $2(5)$ & $0(0)$ & $2(14)$ \\
\hline Illness & $11(28)$ & $8^{\star}(31)$ & $3(21)$ \\
\hline HIV-related & 2 & 0 & 2 \\
\hline HCV-related & 2 & 2 & 0 \\
\hline HIV/HCV co-infection & 2 & 1 & 1 \\
\hline Other & $1(2)$ & $1(4)$ & $0(0)$ \\
\hline Unknown & $3(8)$ & $1(4)$ & $2(14)$ \\
\hline
\end{tabular}

In the sensitivity analysis to assess changes in the final model with forced inclusion of the variable for sex, female sex was not significantly associated with mortality (HR 1.56, 95\% Cl $0.81-$ 3.03 ), and the results for other variables were similar to those in the original analysis.

\section{Interpretation}

This study showed that young Indigenous people who use drugs in $\mathrm{BC}$ are dying at an alarming rate, particularly young women and those who use injection drugs. Living with HCV at baseline was the strongest predictor of mortality, and those living with $\mathrm{HCV}$ when they joined the study were nearly 3 times more likely to die than other participants. Previous Cedar Project research has identified relations between historical and lifetime traumas - including having a parent who attended residential school, child welfare involvement and sexual abuse - and HIV and hepatitis C infection. ${ }^{19,27,28}$ In this study, 6 (15\%) of the deaths were attributed to illnesses related to HCV, HIV or HIV/HCV COinfection, despite the participants being less than 40 years of age and living in a setting of universal health care. Left untreated, HIV and HCV contribute to illness and death. A recent study in Vancouver's Downtown Eastside showed that hepatic fibrosis associated with HCV infection was the strongest predictor of mortality, surpassing HIV. ${ }^{29}$ Despite these trends, young Indigenous people continue to face barriers to care, including racism and stigma. ${ }^{30}$ Ensuring access to new HCV therapies is critical to preventing early death.

Overdose was the leading cause of death in this study. Substance use may be a way to cope with trauma; however, it contributes to risk of overdose death. ${ }^{18,31}$ Furthermore, recent experience of a nonfatal overdose was associated with a 3-fold increase in the risk of death, which suggests that the period immediately after a nonfatal overdose may be a critical time for intervention. Recently, BC has declared a public health emergency because of a surge in overdoses related to the introduction of fentanyl and carfentanil into the drug supply, which has substantially increased the urgency of these measures. ${ }^{32}$ Taken together, these

\section{Table 3: Mortality rates among young Indigenous people who use drugs}

\begin{tabular}{|c|c|c|c|c|c|}
\hline Variable & All & Women & Men & Yes & No \\
\hline $\begin{array}{l}\text { Crude mortality rate, per } 100000 \text { population per year } \\
(95 \% \mathrm{CI})\end{array}$ & $670(479-913)$ & $916(598-1342)$ & $447(245-751)$ & $986(674-1392)$ & $294(127-579)$ \\
\hline $\begin{array}{l}\text { Standardized mortality ratio v. Indigenous population } \\
(95 \% \mathrm{Cl}) \ddagger\end{array}$ & $7.8(5.6-10.6)$ & $9.6(6.3-14.1)$ & $5.2(2.8-8.7)$ & $11.1(7.6-15.7)$ & $2.8(1.2-5.5)$ \\
\hline
\end{tabular}


Table 4: Unadjusted survival analysis of variables associated with death

$\begin{array}{ll}\text { Characteristic } & \text { HR (95\% Cl) } \\ \text { Demographic } & \\ \text { Sex, female } & 2.05(1.07-3.92) \\ \text { City, Vancouver } & 1.21(0.65-2.25) \\ \text { Age } & 1.05(0.97-1.13)\end{array}$

\section{Trauma}

Either parent attended residential school Yes

$1.22(0.54-2.73)$

Unsure

$0.83(0.33-2.08)$

Ever removed from biological parents

$0.73(0.39-1.36)$

Childhood sexual abuse

$1.21(0.65-2.24)$

Age at first sexual abuse*

$0.94(0.83-1.06)$

Ever attempted suicide

$1.97(1.06-3.66)$

Ever incarcerated

$1.82(0.87-3.82)$

Ever admitted to hospital for mental illness

$1.19(0.55-2.58)$

Ever diagnosed with mental illness

$1.65(0.88-3.10)$

Ever thought about suicide

$1.71(0.89-3.27)$

Slept on the streets for $\geq 3$ nights (recent)

$0.67(0.29-1.51)$

Thought about suicide (recent)

$0.78(0.20-3.03)$

Incarcerated (recent)

$1.33(0.68-2.63)$

\section{Substance use}

Age at first non-injection drug use $\dagger$

$0.93(0.84-1.02)$

Ever injected

$3.36(1.55-7.29)$

Age at first injection

$0.96(0.88-1.05)$

Ever overdosed

$1.46(0.77-2.78)$

Injection drug use (recent)

$1.98(1.04-3.77)$

Binge injection drug use (recent)

Binge non-injection drug use (recent)

$2.52(0.99-6.45)$

$1.24(0.60-2.54)$

Alcohol binge (recent)

$1.40(0.62-3.17)$

Daily or more injection of cocaine (recent)

$2.81(1.16-6.79)$

Daily or more injection of crystal

$1.15(0.28-4.79)$

methamphetamine (recent)

Daily or more injection of opiates (recent)

$2.41(1.22-4.77)$

Overdose (recent)

$3.11(1.10-8.79)$

Ever methadone treatment

$1.90(0.93-3.89)$

Methadone treatment (recent)

$2.04(0.90-4.62)$

\section{Sexual vulnerability}

Ever been paid for sex

$1.42(0.76-2.63)$

Sexual assault (recent)

$1.91(0.46-7.94)$

Sex work (recent)

$1.58(0.74-3.40)$

\section{HIV or HCV infection}

HIV infection

$1.77(0.84-3.73)$

HCV infection

$2.22(1.16-4.26)$

Note: $\mathrm{Cl}=$ confidence interval, $\mathrm{HCV}=$ hepatitis $\mathrm{C}$ virus, $\mathrm{HR}=$ hazard ratio, "recent" = previous $6 \mathrm{mo}$.

*Among the subset of people who reported sexual abuse.

$\dagger$ Among the subset of people who reported injection drug use. findings highlight the pressing need for trauma-informed harm reduction services and supports that prioritize culturally safe opportunities for healing. ${ }^{33}$

Deep-seated pain affecting generations of young Indigenous people may also lead to rejection of life itself. ${ }^{34,35} \mathrm{It}$ is possible that some of the overdoses observed were in fact suicides. Previous Cedar Project findings have shown that in as many as $35 \%$ of suicide attempts, the method was overdose, with young women more likely than men to use this method. ${ }^{34}$ In the current study, suicide by means other than overdose was the cause of death among 5 participants, including 4 young women. In addition, those who had ever attempted suicide at baseline were nearly 2 times more likely to die. Suicide prevention must include a holistic approach to mental wellness that incorporates Indigenous ways of knowing, including ceremony, traditional languages and culture. ${ }^{36}$

In the current study, young women experienced mortality rates almost double those of young men. They were 9.6 times more likely to die than other Indigenous people, and 15.8 times more likely to die than all Canadians. In particular, young women were overrepresented among deaths by suicide (4/5 or $80 \%)$, overdose $(11 / 15$ or $73 \%)$ and illness (8/11 or $73 \%)$, compared with young men. However, sex was not significantly associated with mortality in our final model, which may show that sex per se is not biologically associated with mortality but rather that HCV, suicide and fatal overdose are highly gendered among Indigenous people, as previously highlighted by the Cedar Project and others. ${ }^{27,37-39} \mathrm{It}$ is essential that young Indigenous women who use drugs are meaningfully involved in the development of programs to support their health and well-being, reduce drugrelated harms and remove barriers to care.

Homicide accounted for 2 deaths in this study; both involved young men, consistent with higher rates of homicide among men than women ${ }^{40}$ In 2014, 23\% of homicides in Canada involved Indigenous victims, despite this group accounting for just $5 \%$ of the population. ${ }^{41}$ Indigenous men were 3 times more likely than Indigenous women to be victims of homicide, and 7 times more likely to experience homicide than non-Indigenous men. ${ }^{41} \mathrm{Homi}$ cide was not listed as a cause of death for any of the young women in our study, despite profound risks of violence and murder among Indigenous women. ${ }^{7,8}$ This may be a result of systemic bias in ruling out homicide. Families of Indigenous women whose deaths have been deemed suicides or overdoses continue to call into question official rulings that claim no evidence of foul play, urging

Table 5: Multivariable stepwise analysis of variables associated with death

\section{Variable}

$\mathrm{HCV}$ (at baseline)

Ever attempted suicide

Overdose in past 6 mo

Age at first non-injection drug use
Adjusted $\mathrm{HR}^{\star}(95 \% \mathrm{Cl})$

$2.76(1.47-5.16)$

1.88 (1.01-3.50)

$2.85(1.00-8.09)$

$0.94(0.86-1.03)$
Note: $\mathrm{Cl}=$ confidence interval, $\mathrm{HCV}=$ hepatitis $\mathrm{C}$ virus, $\mathrm{HR}=$ hazard ratio.

${ }^{\star}$ Each HR was adjusted for the other variables in this table. 
that their loved ones be included in the National Inquiry into Missing and Murdered Indigenous Women and Girls. ${ }^{8,42,43}$

Our previous findings have identified associations between child welfare involvement and risk factors for death, including suicide attempt (adjusted odds ratio [OR] 1.4, 95\% Cl 1.0-2.1) and, among those who have injected drugs, overdose (adjusted OR 2.7, 95\% Cl 1.6-4.5). ${ }^{28}$ Among Cedar Project participants, childhood sexual abuse has also previously been found to be associated with attempted suicide (adjusted OR 1.91, 95\% Cl 1.27-2.87), ${ }^{44}$ which was a predictor of death in this study. Lack of direct associations between historical and lifetime traumas and mortality in this analysis may be a result of insufficient statistical power or the fact that statistical association is not necessarily transitive. Although temporally distant from death, experiences of intergenerational and lifetime traumas may prompt harmful stress coping, including injection drug use and self-harm, resulting in the proximal predictors of death observed in the current study. ${ }^{31}$ Our previous work indicates that we cannot discount these experiences in understanding the risk of death.

Our Indigenous governance reminds us that these deaths involve our relations ${ }^{2}$ and "carr[y] with them personal sorrow and family desolation that cannot be described statistically." Young people who use drugs, as well as their families, must have access to culturally safe resources to support healing and coping with grief.

\section{Limitations}

This study was subject to limitations. It may be that some deaths went undocumented, and the cause of death may have been misclassified in some cases. Because it is challenging to obtain a probabilistic sample, it is possible that our results are not fully generalizable. However, we know of no population-based sample of Indigenous young people who use drugs with which we could compare our findings. Any study of this hard-to-reach population would likely use sampling similar to what we used. With the exception of HIV and HCV infection, all variables were self-reported. Participants may have underreported experiences that were painful or stigmatizing. We cannot draw conclusions about causality. The small sample size lowered the likelihood of finding statistical significance and limited the number of covariables that could be adjusted for in multivariable models. Given that all participants in our cohort are Indigenous, we were unable to compare predictors of mortality by ethnicity (e.g., between Indigenous and non-Indigenous young people who use drugs). Despite these limitations, this study provides important epidemiologic evidence, not previously reported, regarding elevated mortality among young Indigenous people who use drugs.

\section{Conclusion}

The death rates among young Indigenous people who use drugs reported in this study are appalling and must be viewed as a public health and human rights issue. In the time since this analysis was completed, an additional 25 young men and women in the Cedar Project cohort have passed away (as of September 2017). This study underscores that young Indigenous people who use drugs continue to be affected by historical and present-day injus- tices, substance use and barriers to care. Yet Indigenous traditions, languages, culture and spirituality have survived and continue to form the basis of resilience and resistance among young Indigenous people who use drugs. ${ }^{33,36}$ Trauma-informed programs that build on young people's strengths and cultural identities are critical to putting a stop to these untimely deaths.

\section{References}

1. John E. Indigenous resilience, connectedness and reunification - from root causes to root solutions: a report on Indigenous child welfare in British Columbia. Chilliwack (BC): Ministry of Children and Family Development; 2016.

2. Christian WM, Spittal PM. The Cedar Project: acknowledging the pain of our children. Lancet 2008;372:1132-3.

3. Attawapiskat chief implores Trudeau for meeting, cites 9 more suicide attempts this week. CBC News; 2016 May 5. Available: www.cbc.ca/news/canada/sudbury/ attawapiskat-suicide-attempts-letter-chief-1.3567624 (accessed 2017 Feb. 8)

4. Fact sheet: urban Aboriginal population in Canada. Ottawa: Indigenous and Northern Affairs Canada; 2016.

5. The health and well-being of the Aboriginal population: interim update [Provincial Health Officer's Special Report]. Victoria: Office of the Provincial Health Officer; 2012.

6. Tjepkema M, Wilkins R, Senécal S, et al. Mortality of urban Aboriginal adults in Canada, 1991-2001. Chronic Dis Can 2010;31:4-21.

7. Pearce M. An awkward silence: missing and murdered vulnerable women and the Canadian justice system [dissertation]. Ottawa: University of Ottawa; 2013.

8. Missing and murdered Aboriginal women: a national operational overview. Ottawa: Royal Canadian Mounted Police; 2014.

9. Kelm ME. Colonizing bodies: Aboriginal health and healing in British Columbia, 1900-50. Vancouver: University of British Columbia Press; 1999.

10. Honouring the truth, reconciling for the future: summary of the final report of the Truth and Reconciliation Commission of Canada. Winnipeg: Truth and Reconciliation Commission of Canada; 2015.

11. Erasmus G, Dussault R. Report of the Royal Commission on Aboriginal Peoples. Ottawa: The Royal Commission on Aboriginal Peoples; 1996.

12. Chansonneuve D. Reclaiming connections: understanding residential school trauma among Aboriginal people. A resource manual. Ottawa: Aboriginal Healing Foundation; 2005.

13. Mosby I. Administering colonial science: nutrition research and human biomedical experimentation in Aboriginal communities and residential schools, 1942-1952. Hist Soc 2013;46:145-72.

14. Final report of the Truth and Reconciliation Commission of Canada. Volume 4: Canada's residential schools: missing children and unmarked burials. Winnipeg: Truth and Reconciliation Commission of Canada; 2015.

15. Blackstock C. First Nations Child and Family Services: restoring peace and harmony in First Nations Communities. In: Kufeldt K, McKenzie B, editors. Child welfare: connecting research policy and practice. Waterloo (ON): Wilfred Laurier University Press; 2003: 331-43.

16. Aboriginal peoples in Canada: First Nations people, Métis and Inuit, National Household Survey 2011. Ottawa: Statistics Canada; 2011. Cat. no. 99-011-X.

17. A review of the mortality experience of children and youth in care: 1986 to 2005, British Columbia [updated technical report]. Victoria: Office of the Provincial Health Officer; 2006.

18. Chansonneuve D. Addictive behaviours among Aboriginal people in Canada Ottawa: Aboriginal Healing Foundation; 2007.

19. Spittal PM, Craib KJ, Teegee M, et al. The Cedar Project: prevalence and correlates of HIV infection among young Aboriginal people who use drugs in two Canadian cities. Int J Circumpolar Health 2007;66:226-40.

20. Table 102-0504: Deaths and mortality rates, by age group and sex, Canada, provinces and territories. Ottawa: Statistics Canada; 2008.

21. First Nations health and well-being: interim update. Victoria: Office of the Provincial Health Officer, First Nations Health Authority; 2015.

22. Graham JW, Olchowski AE, Gilreath TD. How many imputations are really needed? Some practical clarifications of multiple imputation theory. Prev Sci 2007;8:206-13.

23. Little RJ, Rubin DB. Statistical analysis with missing data. 2nd ed. Hoboken (NJ): John Wiley \& Sons; 2014.

24. Hosmer DW, Lemeshow S. Applied survival analysis: regression modelling of time to event data. Hoboken (NJ): John Wiley \& Sons; 1998.

25. Wood AM, White IR, Royston P. How should variable selection be performed with multiply imputed data? Stat Med 2008;27:3227-46.

26. Lumley T. Mitools: tools for multiple imputation of missing data. Available: https:// cran.r-project.org/web/packages/mitools/index.html (accessed 2015 Oct. 27). 
27. Craib KJ, Spittal PM, Patel SH, et al. Prevalence and incidence of hepatitis C virus infection among Aboriginal young people who use drugs: results from the Cedar Project. Open Med 2009;3:e220.

28. Clarkson AF, Christian WM, Pearce ME, et al. The Cedar Project: negative health outcomes associated with involvement in the child welfare system among young Indigenous people who use injection and non-injection drugs in two Canadian cities. Can J Public Health 2015;106:e265-70.

29. Jones AA, Vila-Rodriguez F, Leonova $\mathrm{O}$, et al. Mortality from treatable illnesses in marginally housed adults: a prospective cohort study. BMJ Open 2015;5:e008876.

30. Allan B, Smylie J. First Peoples, second class treatment: the role of racism in the health and well-being of Indigenous peoples in Canada. Toronto: The Wellesley Institute; 2015

31. Walters KL, Simoni JM, Evans-Campbell T. Substance use among American Indians and Alaska natives: incorporating culture in an" indigenist" stresscoping paradigm. Public Health Rep 2002;117(Suppl 1):S104-17.

32. Provincial health officer declares public health emergency [news release]. BC Gov News 2016 Apr. 14. Available: https://news.gov.bc.ca/10694 (accessed 2017 Feb. 13).

33. Honouring our strengths: a renewed framework to address substance abuse issues among First Nations people in Canada. Ottawa: Assembly of First Nations, National Native Addictions Partnership Foundation, Health Canada; 2010.

34. Moniruzzaman A, Pearce ME, Patel SH, et al. The Cedar Project: correlates of attempted suicide among young aboriginal people who use injection and noninjection drugs in two Canadian cities. Int J Circumpolar Health 2009;68:261-73.

35. Adelson N. The embodiment of inequity. Can J Public Health 2005;96(Suppl 2): S45-61.
36. First Nations mental wellness continuum framework - summary report. Ottawa: Health Canada, Assembly of First Nations; 2015.

37. Mehrabadi A, Paterson K, Pearce M, et al. Gender differences in HIV and hepatitis $C$ related vulnerabilities among Aboriginal young people who use street drugs in two Canadian cities. Women Health 2008;48:235-60.

38. Milloy MJ, Wood E, Reading C, et al. Elevated overdose mortality rates among First Nations individuals in a Canadian setting: a population-based analysis. Addiction 2010;105:1962-70.

39. Buxton JA, Skutezky T, Tu AW, et al. The context of illicit drug overdose deaths in British Columbia, 2006. Harm Reduct J 2009;6:9.

40. Brzozowski JA, Taylor-Butts A, Johnson S. Victimization and offending among the Aboriginal population in Canada. Ottawa: Statistics Canada, Canadian Centre for Justice Statistics; 2006. Cat. no. 85-002-XIE.

41. Homicide in Canada, 2014. Ottawa: Statistics Canada; 2015. Cat. no. 85-002-x.

42. Smith J. Tragedy of missing, murdered indigenous women bigger than numbers, Carolyn Bennett says. The Star [Toronto]; 2016 Feb. 16.

43. Moore H, Troian M. "No foul play" found in deaths of dozens of Indigenous women, but questions remain: $C B C$ investigation finds suspicious circumstances in deaths ruled accidental or suicidal. CBC News; 2016 June 28. Available: www.cbc.ca/beta/news/canada/manitoba/unresolved-cases-of-missing -and-murdered-indigenous-women-1.3651516 (accessed 2017 Sept. 19).

44. Cedar Project Partnership; Pearce ME, Christian WM, Patterson K, et al. The Cedar Project: historical trauma, sexual abuse and HIV risk among young Aboriginal people who use injection and non-injection drugs in two Canadian cities. Soc Sci Med 2008;66:2185-94.
Competing interests: Eric Yoshida has been an investigator for clinical trials (outside the work reported here) sponsored by Abbvie, Gilead Sciences Inc., Merck Inc., Janssen Inc., Springbank Inc., Intercept Inc. and Genfit Inc.; he has also received honoraria for continuing medical education lectures sponsored by Gilead Sciences Canada Inc., Merck Canada Inc. and Celgene Canada Inc. Patricia Spittal has received grants from Gilead for cultural safety supports and from Merck for an HCV blanket program. No other competing interests were declared.

This article has been peer reviewed.

Affiliations: School of Population and Public Health (Jongbloed, Sharma, Blair, Schechter, Spittal), Department of Chemical and Biological Engineering (Zamar), and Faculty of Medicine, Division of Gastroenterology (Yoshida), The University of British Columbia; Canadian HIV Trials Network (Pearce); Canadian Aboriginal AIDS Network (Pooyak [Cree]); The Cedar Project, BC Children's Hospital Research Institute (Thomas [Wuikinuxv Nation]), BC Children's Hospital; Vancouver Native Health Society (Demerais [Cree, Métis]), Vancouver, BC; Splatsin te Secwepemc (Christian [Splatsin te Secwepemc]); Department of First Nations Studies (Henderson [Cree, Métis]), University of Northern British Columbia, Prince George, BC; Division of Gastroenterology (Yoshida), Vancouver General Hospital, Vancouver, BC
Contributors: Kate Jongbloed contributed to study conception, data collection and research design, and led manuscript development. Margo Pearce contributed to study conception, research design, manuscript development and review. Vicky Thomas contributed to data collection and to manuscript development and review. David Zamar contributed to the analysis and to manuscript development and review. Sherri Pooyak, Lou Demerais, Wayne Christian, Earl Henderson and the Cedar Project Partnership provided input on Indigenous research methods and cultural safety in study protocols and procedures, as well as contributing to research design and data interpretation and to revising the manuscript critically for important intellectual content. Richa Sharma, Alden Blair and Eric Yoshida contributed to interpreting the data and revising the manuscript critically for important intellectual content. Martin Schechter and Patricia Spittal contributed to study conception, interpretation of the data, and manuscript development and review. All of the authors gave final approval of the version to be published and agreed to be accountable for all aspects of the work.

Members of the Cedar Project Partnership: Elders Violet Bozoki (Lheidli T'enneh) and Earl Henderson (Cree, Métis), Prince George Native Friendship Centre, Carrier Sekani Family Ser- vices, Positive Living North, Red Road Aboriginal HIV/AIDS Network, Central Interior Native Health, Vancouver Native Health Society, Canadian Aboriginal AIDS Network, All Nations Hope, Splatsin Secwepemc Nation, Neskonlith Indian Band and Adams Lake Indian Band.

Funding: The Cedar Project receives ongoing support from the Canadian Institutes of Health Research, which has no role in the preparation of data or manuscripts.

Acknowledgements: The authors are indebted to the Cedar Project participants for continuing to share their stories. They extend special thanks to members of the Cedar Project Partnership for their conviction and for holding the research team accountable to the voices of young Indigenous people. The authors also thank the Elders who supported this study for continued wisdom and guidance. The authors are grateful to past and present study staff Sharon Springer, Amanda Wood, Matt Quenneville, Pearl Lau, Jill Fikowski and Janene Erickson - who bring tremendous care and energy to this work.

Accepted: June 22, 2017

Correspondence to: Patricia Spittal, spittal@ sm.hivnet.ubc.ca

smivnet.ubc.ca 